\title{
Governing sustainable tourism in time of COVID-19 disaster: empirical evidence from Bintan, Kepulauan Riau
}

\author{
Mahadiansar Mahadiansar ${ }^{1 *}$, Andy Fefta Wijaya ${ }^{1}$, Alfi Haris Wanto ${ }^{1}$, Wayu Eko Yudiatmaja ${ }^{2}$, and Ramadhani \\ Setiawan $^{2}$ \\ ${ }^{1}$ Department of Public Administration, Brawijaya University, Malang, Indonesia \\ ${ }^{2}$ Department of Public Administration, University of Maritim Raja Ali Haji, Tanjungpinang, Indonesia
}

\begin{abstract}
The COVID-19 disaster has brought various negative effects on human activities, including the tourism sector. However, only a few studies have conducted to the development and governance of tourism by the stakeholders during the COVID-19 pandemic. The purpose of this study is to explain the governance of sustainable tourism during the COVID-19 outbreak. The research was conducted in Bintan Regency, Kepulauan Riau, by using a qualitative approach. The data were collected using an interview with several tourism stakeholders, involving business actors, resort owners, government, and village officials. The results suggest that the governing process of tourism in Bintan focused on formal policy and implementation. The government and business actors become crucial actors in helping the sustainability of tourism during the COVID-19 pandemic. The study can be used as a valuable recommendation to the government in managing tourism in the era of COVID-19.
\end{abstract}

\section{Introduction}

Bintan Regency has very strategic tourism potential, since it has direct borders with neighboring countries, that is, Singapore and Malaysia. Thus, the number of tourist visits, both domestic and foreign tourists is the main contributor to Regional Original Income (PAD). Based on data from the Central Statistics Agency (BPS) of Bintan Regency, the increase in the number of tourists in 2016 was 305,404 people, in 2017 was 368,592 people and in 2019 was 522,399 people [1].

An understanding of sustainable tourism policy that depends on institutional sustainability is essential. Practically, in the sustainable development process, the completion of the basics of sustainable governance is always missed it is to ensure equity in the tourism development policy process[2]. However, not much known about the types of governance processes and instruments that can effectively synergize economic, ecological, and social interests in the tourism sector [3]. Sustainable tourism is an interconnected concept involving all sectors, including economic, social, cultural and political [4].

Sustainable tourism is not about forecasting or a case study of what will happen now and in the future. The development of tourism in Bintan Regency socially is very helpful as an additional income besides the profession as fishermen. The impacts in the implementation of tourism policies will involve stakeholder including communities around areas that have sustainable tourism potentials to be developed.

Implementation development of sustainable tourism policies has a problem or phenomenon occur both formally and informally, such as studies by Prasetyanti et al.[5]. Ceballos-Lascuráin highlights the basics of sustainable tourism policies managed by multiple stakeholders [6]. This study aims to analyze sustainable tourism policies during the COVID-19 pandemic. The questions in this study can be formulated as follows: (1) How is the implementation and policy of sustainable tourism during the COVID-19 pandemic? (2) How is Tourism Governance during the COVID-19 pandemic in Bintan Regency?

\section{Research Methods}

This research is qualitative research with a case study approach [7]. Case study research is conducted to explore unique and interesting cases in certain limited systems. Case studies are also more detailed in describing a phenomenon by collecting data directly [8]. Primary data were obtained through interviews with several informants, which included the Head of the Bintan Regency Culture and Tourism Office, the Head of the Bintan Regency Village and Empowerment Agency, the Head of the Bintan Regency Malay Customary Institution, the Head of Teluk Bakau Village, the BBC Tourism Manager (Bintan Blue Coral), and Raja Ali Haji Maritime University Academic (Tourism Policy Expert Staff).

\footnotetext{
* Corresponding author: mahadiansar@student.ub.ac.id
} 
The instrument in this study adopts the concept of implementation of sustainable tourism development policies with indicators covering several aspects, namely: the content of policy and context of implementation [9]. Content of policy consists of interest that is affected, the type of benefits, the change of degree, the point of the decision-making, implementation of the program, and used resources. The context of implementation consists of the power, importance, and strategies of the actors involved, the characteristics of institutions and regimes, compliance, and responsibility. The analytical method used in this research is the qualitative analysis by analyzing the problem by looking for solutions and strategies through using case study analysis. Data analysis consists of examining, grouping, tabulating, testing, or recombining evidence, to generate findings based empirically using the Nvivo 12 Pro application [10].

\section{Results}

\subsection{Bintan Tourism Condition}

Bintan Regency is one of 4 regencies and 2 cities in the Riau Islands Province based on Law no. 25/2002 (BPS Kepri, 2020). Based on data from the Riau Islands BPS, (2020) there are around 241 islands in the Bintan Regency area. With a large number of islands and a strategic location with foreign countries, namely Singapore and Malaysia, Bintan has become one of the destinations for foreign tourists to vacation. Bintan has 61 tourist attractions, 31 tours \& travels, 24 tour groups, and 51 hotels and resorts spread across the Bintan Regency (Bintan Culture and Tourism Office, 2021). Here are some locations for tourism development in Bintan, namely:

1. Sebong Pereh as an Eco-Tourism area (Mangrove tourism and Tourism Village),

2. Bintan Bunyu as an Eco-Tourism area (Mount Bintan, Tourism Village, and camping location),

3. Bintan Integrated Resort (Beach, Golf, Mall, etc.),

4. Trikora Beach (White Sand Beach, Cottage, Water Tourism, Snorkeling, Diving, Fishing Locations, and Fishing Village), and

5. Batu Licin as a new Resort development.

Due to a large number of tourist sites and accommodations, Bintan Regency in 2019 attracted $1,094,442$ visitors both local and foreign tourists. However, the pandemic hit the tourism industry in Bintan. Data shows that during the COVID-19 pandemic the number of tourist visits to Bintan Regency decreased drastically by $81.49 \%$, in 2020 the number of visits to Bintan Regency was only 202,583 visitors (Bintan Culture and Tourism Office, 2021).

Based on the table of coding results above, shows that some of the sources of tourism activities in Bintan Regency have stopped globally. However, sustainable tourism governance is only focused on local communities while maintaining health protocols. Bintan Regency Tourism currently only expects government policies to open border access, but the impact of the break of global tourism in the district has an impact at a loss of employment as if they are laid off or laid off en masse.
Table 1. Bintan Regency Tourism Coding Results During the COVID-19 Pandemic

\begin{tabular}{|c|c|}
\hline Interviewees & Statement \\
\hline \multirow[b]{2}{*}{$\begin{array}{l}\text { BBC Tourism } \\
\text { Manager }\end{array}$} & When COVID tourism activities fall. \\
\hline & $\begin{array}{l}\text { Since the border was closed during } \\
\text { pandemics (all tourists } 90 \% \text { come } \\
\text { from Singapore), the tourist comes from } \\
\text { Singapore, so no tourists. The number of } \\
\text { employees on weekdays Monday - } \\
\text { Friday ( } 8 \text { employees) / previously used to } \\
\text { be around } 100 \quad \text { more } \\
\text { employees. Currently, expecting only } \\
\text { local tourists }\end{array}$ \\
\hline \multirow[b]{2}{*}{$\begin{array}{l}\text { Malay } \\
\text { Customary } \\
\text { Institution }\end{array}$} & No cultural events after COVID. \\
\hline & $\begin{array}{l}\text { After COVID there are no integrated } \\
\text { cultural and tourism activities. However, } \\
\text { the youth of Bintan initiate small-scale } \\
\text { cultural and tourism activities in the } \\
\text { villages by obeying the health protocols. }\end{array}$ \\
\hline \multirow{3}{*}{$\begin{array}{l}\text { Head of the } \\
\text { Mangrove } \\
\text { Bay Village }\end{array}$} & $\begin{array}{l}\text { There are plans such as combining } \\
\text { culture and tourism through dance and } \\
\text { culture. This program was only running } \\
\text { before COVID. Still not sure because I'm } \\
\text { still afraid of the stigma of COVID. }\end{array}$ \\
\hline & $\begin{array}{l}\text { People are afraid of the stigma of } \\
\text { COVID, there are pros and cons during } \\
\text { the pandemic. They were afraid that } \\
\text { COVID would spread in their area, but } \\
\text { after the Regent, Governor, and health } \\
\text { experts arrived. After socialization, the } \\
\text { community understands this. }\end{array}$ \\
\hline & $\begin{array}{l}\text { During COVID, some foreign investors, } \\
\text { businessmen, keep visiting to ask for } \\
\text { coastal land. But, most of the coastal land } \\
\text { has been run out. Some Japanese } \\
\text { investors/entrepreneurs want to open } \\
\text { investments and build, but there is no } \\
\text { land available. }\end{array}$ \\
\hline $\begin{array}{c}\text { Head of the } \\
\text { Department } \\
\text { of Culture and } \\
\text { tourism }\end{array}$ & $\begin{array}{l}\text { During COVID, the Lagoi ferry only } \\
\text { operates once a week but no one enters } \\
\text { because the border is still closed. }\end{array}$ \\
\hline
\end{tabular}

\subsection{Content of Policy}

As pandemic COVID-19 takes place, there are several rules and decisions issued by the government in the form of government regulation, Kementerian, Institutions, and the Force in an attempt to prevent the spread of COVID19, the following is a regulation that affects Bintan tourism:

1. Regulation of the Minister of Law and Human Rights No. 11 of 2020 concerning the Prohibition of Foreigners from Entering the Territory of the Archipelago State of the Republic of Indonesia,

2. Circular Letter (SE) Task Force of the COVID-19 No. 12 of 2021 concerning the Extension of Domestic Travel Provisions, and

3. Guidelines for the Implementation of the Ministry of Tourism and Creative Economy policies in the form of the implementation of CHSE (Cleanliness, Health, Safety, and Environmental Sustainability) in the Tourism Industry which refers to the Decree of the Minister of Health of the Republic Indonesia Number HK.01.07/MENKES/382/2020 regarding Public Health 
Protocols in Places and Facilities General In the Context of Prevention and Control of COVID-19.

Based on the explanation, the content of policy focuses on rules and regulations that must be obeyed by local governments and other stakeholders in handling the COVID-19 pandemic in Bintan Regency tourism activities in the implementation of CHSE. The latest data shows the number of tourism industries in Bintan Regency that have a satisfactory CHSE category is 47 (forty-seven), the tourism industry can be seen in Table 2.

Table 2. Bintan Tourism Industry with Satisfactory CHSE

\begin{tabular}{|c|l|c|}
\hline No & \multicolumn{1}{|c|}{ Tourism Industry } & Amount \\
\hline 1 & Tourist Transport & 1 \\
\hline 2 & Tourist attraction & 2 \\
\hline 3 & Home stay / Pondok Wisata & 9 \\
\hline 4 & Hotel & 23 \\
\hline 5 & Restaurant & 10 \\
\hline 6 & Golf Business & 2 \\
\hline \multicolumn{2}{|c|}{ Amount } & 47 \\
\hline
\end{tabular}

The CHSE certification policy was established by the Ministry of Tourism and Creative Economy of the Republic of Indonesia as a guide for the implementation of CHSE which includes Hygiene, Health, Safety, and Environmental Sustainability. There are 11 guidelines in the implementation of CHSE [11], including the Tourist Attraction Guide, Hotel Guide, Homestay Guide, MICE Guide (Meetings, Incentives, Conferencing, Exhibitions), Event Organizing Guide, and so on. The implementation of the CHSE certification is intended as one of the efforts in preventing and handling COVID-19 in the tourism sector [12][13]. The guidelines it is described in great detail as an example in the Hotel Guide about tools of Health Protocols, optimization of air circulation, the implementation of the cleaning and disinfecting, entrances, rooms, meeting rooms, dining room, swimming pool, fitness center, mosque, and other public facilities in the business area.

\subsection{Context of Implementation}

The implementation of the Health Protocol and CHSE certification goes well because humans need to stay alive. The implementation of CHSE and the Health Protocol received a positive response based on the respondents' results. In addition, the Government in this case assists in the form of providing the tools of Health Protocol, implementing certification, and the implementing of vaccines is welcomed. Some expectations from respondents are the implementation of the vaccine will be accomplished immediately for all groups not only for tourism employees thus tourists feel safe when doing tourism activities. The CHSE certification is expected to build the confidence of potential tourists by knowing that the locations visited have followed the CHSE standards implemented by the Government.

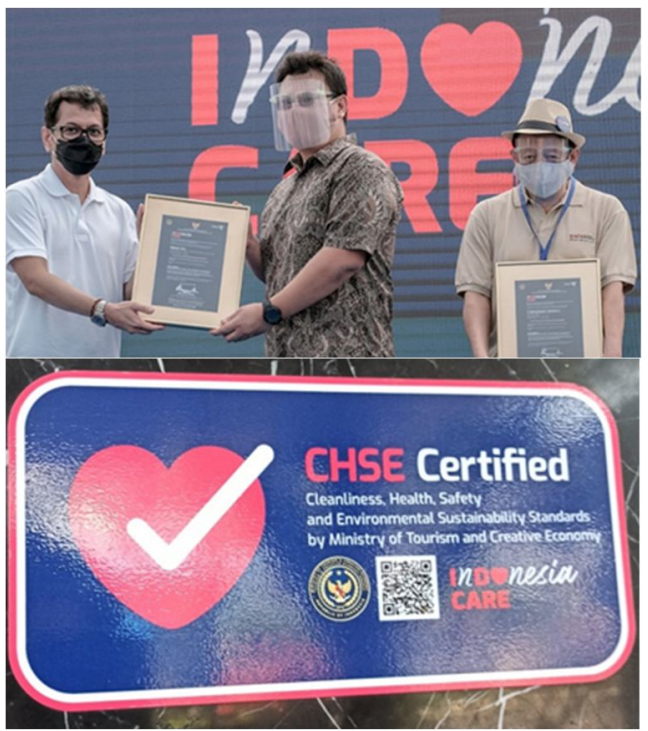

Fig. 1. The Implementation of CHSE in Bintan Regency.

\section{Discussion}

Tourism governance aims to take strategic actions for the public interest in general so that during the COVID-19 pandemic it can be well controlled, this aims to ensure that every stakeholder can carry out their duties for tourism in Bintan Regency adjusts to new adaptations. By looking at governance in the grindle concept, here are the results of the connection map analysis in Content of Policy and Context of Implementation using NVivo 12 Pro

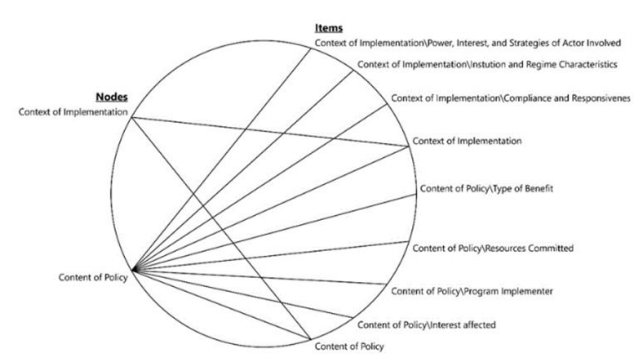

Fig. 2. Connection Map of Tourism Governance on the Grindle Concept during the COVID-19 pandemic.

Based on the results of interviews with the interviewees, the actors of interest show that the connection map of governance in the tourism sector of Bintan Regency during the COVID-19 pandemic is not all well connected, wherein Content of Implementation only leads to the implementation of the COVID-19 program as of the connection map line remains constant on Content of Implementation. Therefore, the Content of Implementation based on the interview results of the interviewees still provides an explanation of Content of Policy in general, which is not able to describe the explanation in terms of Content of Policy dimensions. Furthermore, in the Content of Policy based on the results of interviews with interviewees, it can be concluded the dimensions of Content of Policy influence each other's involvement in the COVID-19 pandemic in the tourism sector in Bintan Regency. 


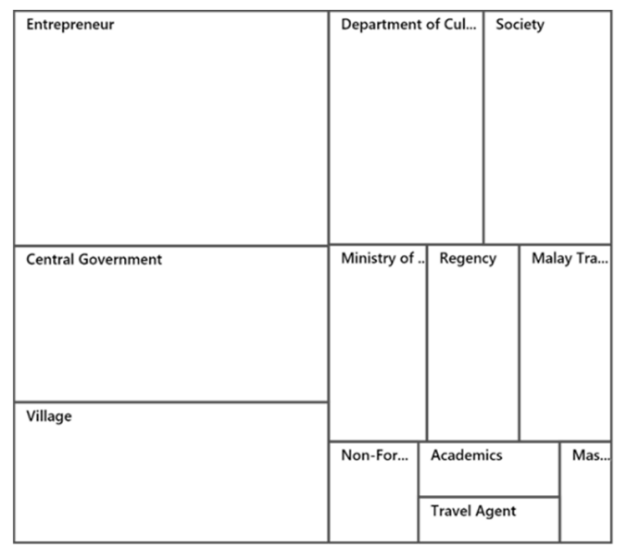

Fig 3. Hierarchy of Tourism Governance during the COVID-19 Pandemic Based on the results of interviewees.

Based on the results of interviewee interviews using NVivo 12 Pro, it shows that the entrepreneur hierarchy is the actor who has the most influence in the development of sustainable tourism during the COVID-19 pandemic. This is the most widely discussed businessman in the interview session on tourism developments during the COVID-19 pandemic. Furthermore, by strengthening tourism governance, the central government positions itself under the entrepreneurs, which means that the central government's attention to entrepreneurs in the tourism sector can be a special concern.

This is due to the Bintan Regency based on BPS Bintan data, Regional Original Income (PAD) in Bintan Regency in the amount to $87 \%$ moves the tourism sector and the income of tourism entrepreneurs dominate in Bintan regency [14]. Therefore, the smallest hierarchy in the mass media, the contribution of the mass media in tourism governance is not significantly involved because the mass media only focuses on tourism conditions during the COVID-19 pandemic and there is no tourism activity in Bintan Regency which is covered by the mass media.

\section{Conclusion}

Based on the results and discussions as well as secondary and primary data, tourism governance in Bintan Regency during the COVID-19 pandemic still focuses on implementation and formal policies. This is the absence of a technical application to the actualization of tourism governance in standard operating procedures (SOP), necessarily tourism governance in the scope of the content of policy and context of implementation dimensions should prioritize the application of tourism governance to formal policies. Thus, technically it presents policy innovations that can make Bintan Regency the concept of sustainable tourism during the COVID-19 pandemic.

\section{References}

1. Oktaviana, R. Feni, A. S. Muhammad, F. Kurnianingsih, Mahadiansar, Internal condition analysis on tourism development of Bintan Regency 2019. Indonesian Journal of Tourism and Leisure 2: 51 (2021).

2. Patterson, Carol Sustainable tourism: business development, operations, and management. II. Human Kinetics (2016).

3. Schroeder, Kent. 2015. Cultural values and sustainable tourism governance in Bhutan. Sustainability (Switzerland) 7. MDPI AG: 16616-16630 (2015)

4. Sharpley, Richard, D. J. Telfer Tourism and Development: Concepts and Issues. Bristol: Channel View Publications (2002).

5. Prasetyanti, Retnayu, I. A. Nugroho Governance, network in sustainable Tourism development: A case of thematic village tourism in Malang, Indonesia. In Proceedings of the Annual International Conference of Business and Public Administration. Poor (2018)

6. Ceballos-Lascuráin, Héctor. 1996. Tourism, ecotourism, and protected areas.Tourism, ecotourism, and protected areas (1996)

7. Miles, Matthew, M. Huberman, J. Saldana Qualitative data analysis. New York: SAGE Publications (2014).

8. Yin, K. Robert, 2018. Case study research and applications: Design and methods. Sixth. Sage Publications (2018).

9. Grindle, M S Politics and policy implementation in the third world. Princeton University Press (2017).

10. Bazeley, Patricia, Qualitative data analysis with NVivo. London: SAGE Publications (2007).

11. Maemunah, Ita. 2021. Implementation of Cleanliness, Health and Environmental Sustainability Guidelines in Restaurants around the Southern Java Crossing Route in Ciamis Regency. Budapest International Research and Critics Institute (BIRCI-Journal): Humanities and Social Sciences 4: 2635-2642 (2021)

12. Syahrin, Alfi Health Protocol Certification for tourism business due to Covid-19 outbreaks in Bali.Journal of Geography of Tropical Environments.5 (2021)

13. Yudiatmaja, Wayu Eko, Dwi Kristanti, Imam Yudhi Prastya, Yudithia Yudithia, Tri Samnuzulsari, Suyito Suyito, and Dian Prima Safitri Social policy on the rural coastal communities: why the implementation fails?. In E3S Web of Conferences 232(1): 02006 (2021).

14. Akbar, Dhani, A. Setiawan, R. Prayuda, A. Putra, A. Aznor, W. E. Yudiatmaja, Community preparedness on transboundary oil spill governance in Bintan island. Journal of Physics: Conference Series, 1655(1): 012144 (2020) 